\title{
The transition of people's preferences for the intervention of the government in the economy of re-unified Germany
}

\author{
Matteo Migheli
}

Received: 23 August 2010/ Accepted: 28 September 2011 / Published online: 30 October 2011 (C) Springer-Verlag 2011

\begin{abstract}
Covering the first fifteen years immediately after German reunification, this paper analyzes the people's support to the transition. The focus is on individuals' preferences for the intervention of the government in the economy and on the opinion about competition per se. Eastern German data are compared with Western German data. Using suitable data that allow for interpersonal comparisons, the paper shows that Eastern Germans have always preferred an intervention of the public hand in the economy deeper than Western Germans; these different positions have hardly converged during the examined period of time. However there are no significant differences with respect to how Germans perceive competition per se: it is considered as a good by the people living in both parts of the country.
\end{abstract}

Keywords Transition - Germany - Individual preferences · Public intervention

JEL Classification D01 $\cdot$ I38 $\cdot$ P35

\section{Introduction}

On November the 9th 1989 the Wall of Berlin felt. During twenty-seven years it had been the material symbol of the post-war division of Germany and Europe into two blocks: the communist one strictly controlled by the U.S.S.R. on the East side, and the liberist one linked to the U.S.A. on the West side. Eleven

\footnotetext{
Electronic supplementary material The online version of this article (doi:10.1007/s10258-011-0078-8) contains supplementary material, which is available to authorized users.

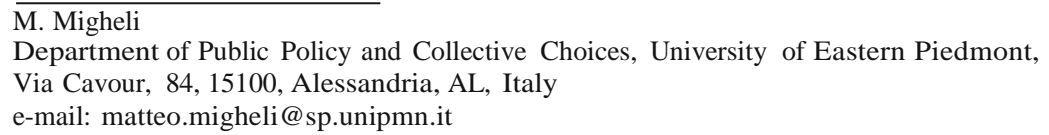

